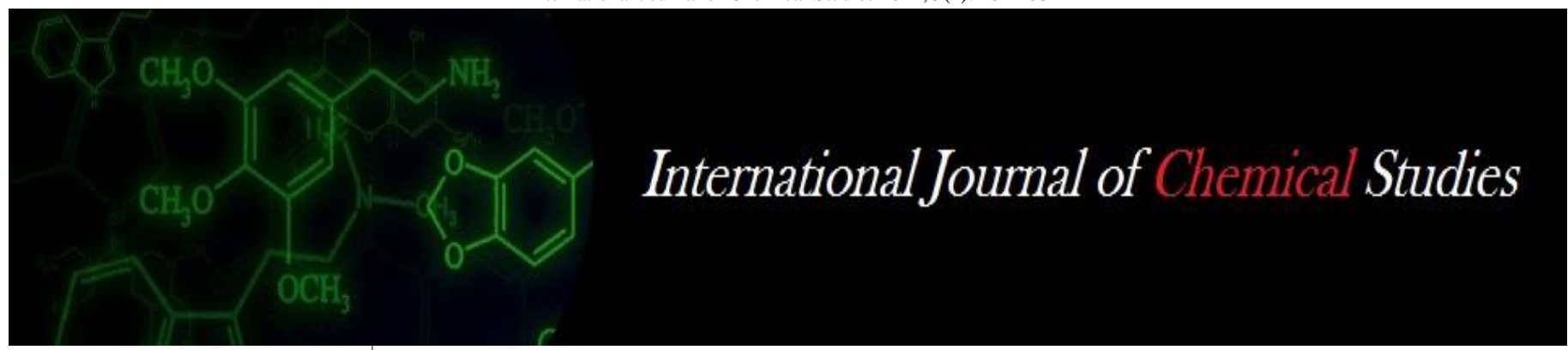

P-ISSN: 2349-8528

E-ISSN: 2321-4902

www.chemijournal.com

IJCS 2021; 9(1): 264-268

(C) 2021 IJCS

Received: 08-10-2020

Accepted: 18-11-2020

\section{Vijaykumar KN}

Department of Plant Pathology,

College of Agriculture, Dharwad,

Karnataka, India

\section{Shripad Kulkarni}

Professor, Department of Plant

Pathology and Nodal officer

(KVK), Directorate of

Extension, University of

Agricultural Sciences, Dharwad,

Karnataka, India

\section{Channakeshava C}

Ph.D., Scholar, Department of

Plant Pathology, College of

Agriculture, Dharwad,

Karnataka, India
Corresponding Author:

Vijaykumar KN

Department of Plant Pathology,

College of Agriculture, Dharwad,

Karnataka, India

\section{Laboratory evaluation of fungi toxic chemicals, botanicals and bioagents against Leveillula taurica causing cluster bean powdery mildew}

\author{
Vijaykumar KN, Shripad Kulkarni and Channakeshava C
}

DOI: https://doi.org/10.22271/chemi.2021.v9.i1d.11237

\begin{abstract}
Powdery mildew caused by Leveillula taurica is an important disease of cluster bean causing the yield loss upto 50-55 per cent. In the present study various systemic, contact, combi product fungicides, bioagents and botanicals have been evaluated in lab condition against Leveillula taurica. Results reveal that among the different fungicides tested, cent per cent conidial germination inhibition was observed with hexaconazole @ $0.1 \%$ and 95.78 per cent inhibition with wettable sulphur @ 0.3\% and 94.72 per cent inhibition with tebuconazole 50\% + trifloxystrobin 25\% @ 0.2\%. Among the different botanicals and bioagents tested, maximum conidial germination inhibition $(80.13 \%)$ was observed with nimbecidine @ 10\% and 56.72 per cent inhibition with Bacillus subtilis @ 1\% concentration.
\end{abstract}

Keywords: In vitro, fungicides, Bacillus subtilis, nimbecidine

\section{Introduction}

Cluster bean is a drought tolerant crop suitable for cultivation under rainfed conditions in arid and semi-arid regions of India. India is the largest producer with 80 per cent of total production in the world. Rajasthan is leading state producing 75 per cent of total production of India. In India, area under cluster bean cultivation is 5.15 million hectares and production of 2.46 million tonnes with a productivity of $478 \mathrm{~kg} \mathrm{ha}^{-1}$ (Anon., 2015) ${ }^{[3]}$.

The cluster bean crop is affected by various biotic and abiotic stresses which are responsible for its poor quality and low yield, resulting in severe economic losses to the country as it is an important cash crop with a great potential for foreign exchange. Among the foliar diseases, powdery mildew caused by Leveillula taurica is an important disease causing the yield loss upto 50-55 per cent. The disease manifests mainly on leaves and pods. Severely affected plants are defoliated and weakened by premature drying and death of infected leaves (Channamma et al., 2015a) ${ }^{[4]}$.

\section{Materials and Methods}

In vitro evaluation of fungicides

In the present study, efficacy of different fungicides at three concentrations was tested against Leveillula taurica by spore germination technique. Required concentrations (mentioned below) of each fungicide were prepared in distilled water. $100 \mu \mathrm{l}$ of fungicide solution was taken on clean cavity slide and $100 \mu \mathrm{l}$ of powdery mildew spore suspension was suspended in fungicide solution on the cavity slide and mixed gently for uniform distribution of spores. Each concentration was replicated thrice in a separate cavity slide. Control treatment was maintained by putting conidia with sterile distilled water. These cavity slides were kept in the Petri dishes lined with moist blotting paper and were incubated at room temperature $(25 \pm 1$ ${ }^{\circ} \mathrm{C}$ ) for $24 \mathrm{hr}$. After 24 hours, 300 spores per microscopic field for each cavity was observed under $10 \mathrm{X}$ and the total number of spores and germinated spores in each microscopic field were recorded and per cent germination was calculated.

Germination $(\%)=\frac{\text { Number of conidia germinated }}{\text { Total Number of conidia observed }}$ 
The average of three cavities (three replications) was found out and the per cent inhibition of spore germination was calculated with the following formula given by Vincent (1927) ${ }^{[14]}$ for each fungicide.

Spore germination inhibition $(\%)=\frac{\mathrm{C}-\mathrm{T}}{\mathrm{C}} \times 100$

\section{Where}

$\mathrm{C}=$ Number of spores germinated in control

$\mathrm{T}=$ Number of spores germinated in treatment

\section{In vitro evaluation of botanicals}

Hundred gram of plant material was cut into small pieces and rinsed in water and macerated using pestle and mortar with $100 \mathrm{ml}$ of distilled water. The content was centrifuged for 5 min at $3000 \mathrm{rpm}$ to get a clear plant extract which serves as the stock solution. Then $5 \mathrm{ml}, 7.5 \mathrm{ml}$ and $10 \mathrm{ml}$ of stock solution was taken separately and made up to $100 \mathrm{ml}$ using distilled water to get $5,7.5$ and 10 per cent concentration respectively. $100 \mu \mathrm{l}$ of plant extract solution was taken on clean cavity slide to which $100 \mu$ l of powdery mildew spores suspension was suspended and mixed gently for uniform distribution of spores. Only sterile distilled water was used as a control. Slides were incubated at temperature $\left(25 \pm 1^{\circ} \mathrm{C}\right)$ for $24 \mathrm{hr}$. After 24 hours, total number of spores and germinated spores in each microscopic field were recorded and per cent germination was calculated.

\section{In vitro evaluation of bioagents}

Four bioagents at two different concentrations (0.5 and 1\%) were tested by spore germination technique. Commercial formulations of these bioagents was collected from Institute of Organic Farming (IOF), University of Agricultural Sciences Dharwad and required concentrations were prepared by adding $0.5 \mathrm{~g}$ in $100 \mathrm{ml}$ of distilled water (for $0.5 \%$ ) likewise one gram of bioagent was added in $100 \mathrm{ml}$ water (for $1 \%$ ). Three replications were maintained for each treatment with only sterile distilled water was used as a control. The slides were incubated at $\left(25 \pm 1^{\circ} \mathrm{C}\right)$ for $24 \mathrm{hr}$. After 24 hours, total number of spores and germinated spores in each microscopic field were recorded and per cent germination was calculated.

\section{Results}

\section{In vitro evaluation of contact fungicides}

Seven contact fungicides were tested under in vitro conditions against Leveillula taurica on inhibition of conidial germination and the results are presented in Table 1. Among all the contact fungicides tested, wettable sulphur was found to be significantly superior over all other fungicides tested and showed maximum inhibition of conidial germination upto 95.78 per cent at 0.30 per cent concentration followed by mancozeb (92.08\%). Minimum inhibition of conidial germination was recorded with zineb $(43.00 \%)$ at 0.10 per cent concentration.

\section{In vitro evaluation of systemic fungicides}

Seven systemic fungicides were tested under in vitro conditions against Leveillula taurica on inhibition of conidial germination and the results are presented in Table 2. Among the fungicides tested, hexaconazole was found to be significantly superior over all other fungicides at 0.1 per cent concentration with cent per cent conidial germination inhibition. However, hexaconazole and propiconazole resulted in cent per cent conidial germination inhibition at 0.15 per cent concentration followed by azoxystrobin with 97.36 per cent inhibition at 0.15 per cent concentration. Minimum inhibition of conidial germination was observed with myclobutanil $(86.81 \%)$ at 0.15 per cent concentration.

\section{In vitro evaluation of combi product fungicides}

Five combi product fungicides were evaluated under in vitro conditions for their efficacy on inhibition of conidial germination of Leveillula taurica and the results are presented in Table 3. Among the combi product fungicides tested with different concentrations, tebuconazole $50 \%+$ trifloxystrobin $25 \%$ (Nativo) was significantly superior over all other treatments with maximum conidial germination inhibition $(94.72 \%)$ at 0.20 per cent concentration followed by metiram $55 \%$ + pyraclostrobin 5\% (Cabrio-Top) which recorded 89.97 per cent inhibition at 0.20 per cent concentration. Minimum conidial germination inhibition was found in carbendazim $12 \%+$ mancozeb $63 \%$ (Saaf) at all the three concentrations mentioned.

\section{In vitro evaluation of botanicals}

Seven botanicals were evaluated under in vitro conditions for their efficacy to inhibit the conidial germination of Leveillula taurica and the results are presented below in Table 4. Among the botanicals evaluated, maximum inhibition $(80.13 \%)$ of conidial germination was found in nimbecidine at 10 per cent concentration which was superior over all other treatments followed by onion bulb extract $(69.57 \%)$ at 10 per cent concentration. Whereas, minimum conidial germination inhibition was found with tulsi leaf extract $(51.63 \%)$ at 10 percent.

\section{In vitro evaluation of bioagents}

Four bioagents were evaluated under in vitro conditions for their efficacy on inhibition of conidial germination of Leveillula taurica and the results are presented in Table 5. Among the various bioagents evaluated, maximum inhibition of conidial germination was found with Bacillus subtilis $(56.72 \%)$ at 1.0 per cent concentration which was significantly superior over all other treatments followed by Pseudomonas fluorescens $(50.13 \%)$ at 1.0 per cent concentration. Minimum conidial germination inhibition was found in Lecanicillium lecanii $(31.39 \%)$ at 0.5 per cent concentration.

\section{Discussion}

Fungicides constitute the predominate part of the control measures used against powdery mildew. Use of newer chemicals has become more popular in recent years because of their quick results, especially in absence of resistant varieties. Among the various fungicides tested hexaconazole found significantly superior over all the fungicides tested and showed cent per cent conidial germination inhibition followed by propiconazole. Several workers reported that, hexaconazole and propiconazole were found to be effective in reducing powdery mildew incidence in different crops (Sharmila et al., 2004; Pramod and Dwivedi, 2007 and Akhileshwari et al., 2012) ${ }^{[13,9,1]}$.

The maximum conidial germination inhibition was found in wettable sulphur. In general, it was observed that with the increase in the concentration, inhibition of conidial germination was also increased as sulphur itself acts as spore killer. Similar findings were recorded by Sharmila et al. (2004) and Channamma et al. (2015a) ${ }^{[13,4]}$. 
Among the triazole fungicides, hexaconazole effectively managed the powdery mildew disease. Hexaconazole is an ergosterol inhibiting fungicide which is essential part of the cell wall and its absence causes irreparable damage, thus fungus dies. They change the sterol content and saturation of the polar fatty acids leading to alterations in membrane fluidity and behaviour of membrane bound enzymes (Nene and Thapliyal, 1993) ${ }^{[8]}$ and also affect the cytochrome P-450 enzyme which is the inhibitor of sterol C-14 demethylation.

Tebuconazole $50 \%$ + trifloxystrobin 25\% (Nativo) showed maximum inhibition. It acts as dimethylase inhibitor by interfering in the process of building structure of fungal cell wall and finally inhibits reproduction and further growth of the fungus. Minimum conidial germination inhibition was found with carbendazim 12\% + mancozeb 63\% (Saaf) $(54.61 \%)$ and these results are in confirmation with Marthand (2016) ${ }^{[7]}$.

Continuous use of chemical fungicides in the management of diseases also brought new problems along with them and alarming among them are the pollution of air, water, residual toxicity in soil and development of resistance of pathogen against fungicides. It has necessitated harmful effect by repeated applications with their escalating prices on nontarget organisms. Botanicals and bioagents are eco-friendly, renewable, inexhaustible, indigenously available, easily assessable, largely non phytotoxic, readily biodegradable and relatively cost effective. Hence, they are easily accommodated in plant protection strategy of integrated disease management.
Screening of plant products and bioagents for their effectiveness and antifungal activity against the pathogen is essentially required to minimize the use of fungicides and to consider them as one of the component in the integrated disease management (Khadar, 1999) ${ }^{[6]}$. The maximum inhibition of conidial germination was found with Bacillus subtilis and least inhibition was observed in Lecanicillium lecanii and these results are in line with Sharma et al. (2002) and Alharbi et al. (2014) ${ }^{[11,2]}$ who studied in vitro bioefficacy of Bacillus spp. and their results indicated significant reduction in conidial germination of $L$. taurica and the reduction per cent was gradually increased by increasing the concentrations tested. They opined that in case of powdery mildew disease, Bacillus subtilis grow on the treated surfaces and invade healthy tissues and utilize available nutrient substances and prevent pathogenic spores to germinate. Bacillus spp. also grows very fast and occupies the court of infection there by preventing pathogen spores to reach susceptible tissues in competition for spaces (Wolk and Sorkar, 1994) ${ }^{[15]}$.

The maximum inhibition of conidial germination was found with nimbecidine and these results are in line with Sharmila (2001) and Channamma et al. (2015b) ${ }^{[12,5]}$ who mentioned that nimbecidine had the high potentiality to enter the spore and exhibit the fungi toxicity. The fungicidal spectrum of neem based product nimbecidine had been investigated by Ravikumar (1998) ${ }^{[10]}$ against the powdery mildew of rose and suppressed the disease effectively.

Table 1: Efficacy of contact fungicides on inhibition of conidial germination of Leveillula taurica

\begin{tabular}{|c|c|c|c|c|c|}
\hline \multirow{3}{*}{ Sl. No. } & \multirow{3}{*}{ Fungicides } & \multirow{2}{*}{\multicolumn{3}{|c|}{$\begin{array}{c}\text { Per cent conidial germination inhibition } \\
\text { Concentrations }(\%)\end{array}$}} & \multirow{3}{*}{ Mean } \\
\hline & & & & & \\
\hline & & 0.1 & 0.2 & 0.3 & \\
\hline 1 & Mancozeb 75\% WP (Indofil M-45) & $86.28(68.23) *$ & $89.97(71.51)^{*}$ & $92.08(73.63)^{*}$ & $89.44(71.01)^{*}$ \\
\hline 2 & Wettable sulphur $80 \%$ WP (Sulfex) & $87.86(69.58)$ & $91.02(72.54)$ & $95.78(78.11)$ & $91.55(73.07)$ \\
\hline 3 & Chlorothalonil 75\% WP (Kavach) & $74.67(59.76)$ & $78.36(62.25)$ & $88.39(70.05)$ & $80.47(63.75)$ \\
\hline 4 & Copper oxychloride 50\% WP (Blue copper) & $49.86(44.90)$ & $56.72(48.84)$ & $60.95(51.30)$ & $55.84(48.33)$ \\
\hline \multirow[t]{2}{*}{5} & Zineb 75\% WP (Indofil Z-78) & $43(40.96)$ & $58.30(49.76)$ & $64.64(53.49)$ & $55.31(48.03)$ \\
\hline & Mean & $68.33(55.73)$ & $74.87(59.89)$ & $80.36(63.67)$ & $74.52(59.66)$ \\
\hline & \multicolumn{2}{|c|}{ S.Em. \pm} & C.D. at $1 \%$ \\
\hline & Fungicides $(\mathrm{F})$ & & \multicolumn{2}{|c|}{0.26} & 0.74 \\
\hline \multicolumn{3}{|c|}{ Concentrations $(\mathrm{C})$} & \multicolumn{2}{|c|}{0.20} & 0.58 \\
\hline \multicolumn{3}{|c|}{$\mathrm{F} \times \mathrm{C}$} & \multicolumn{2}{|c|}{0.44} & 1.30 \\
\hline
\end{tabular}

* Figures in the parenthesis are arc sine transformed value

Table 2: Efficacy of systemic fungicides on inhibition of conidial germination of Leveillula taurica

\begin{tabular}{|c|c|c|c|c|c|}
\hline \multirow{3}{*}{ Sl. No. } & \multirow{3}{*}{ Fungicides } & \multirow{2}{*}{\multicolumn{3}{|c|}{$\frac{\text { Per cent conidial germination inhibition }}{\text { Concentrations }(\%)}$}} & \multirow{3}{*}{ Mean } \\
\hline & & & & & \\
\hline & & 0.05 & 0.1 & 0.15 & \\
\hline 1 & Carbendazim 50\% WP (Bavistin) & $81.52(64.55)^{*}$ & $86.81(68.73)^{*}$ & $90.50(72.06)^{*}$ & $86.27(68.23)^{*}$ \\
\hline 2 & Penconazole 25\% EC (Topaz) & $91.56(73.09)$ & $95.77(78.16)$ & $96.33(79.95)$ & $94.72(76.69)$ \\
\hline 3 & Difenconazole $25 \%$ EC (Score) & $93.14(74.81)$ & $94.20(76.06)$ & $95.78(78.16)$ & $94.37(76.24)$ \\
\hline 4 & Hexaconazole 5\% EC (Contaf) & $96.83(79.72)$ & $100.00(89.96)$ & $100.00(89.96)$ & $98.94(84.07)$ \\
\hline 5 & Myclobutanil 10\% WP (Systhane) & $78.89(62.64)$ & $82.58(65.32)$ & $86.81(68.68)$ & $82.76(65.44)$ \\
\hline 6 & Propiconazole 25\% EC (Tilt) & $96.31(78.94)$ & $97.89(81.73)$ & $100.00(89.96)$ & $98.06(81.97)$ \\
\hline \multirow[t]{2}{*}{7} & Azoxystrobin 23\% SC (Amistar) & $93.14(74.81)$ & $96.83(79.72)$ & $97.36(80.72)$ & $95.78(78.11)$ \\
\hline & Mean & $90.20(71.73)$ & $93.44(75.13)$ & $95.40(77.58)$ & $93.01(74.64)$ \\
\hline \multirow{2}{*}{\multicolumn{3}{|c|}{ Fungicides $(\mathrm{F})$}} & \multicolumn{2}{|c|}{ S.Em. \pm} & C.D. at $1 \%$ \\
\hline & & & \multicolumn{2}{|c|}{0.44} & 1.25 \\
\hline \multicolumn{3}{|c|}{ Concentrations (C) } & \multicolumn{2}{|c|}{0.29} & 0.82 \\
\hline \multicolumn{3}{|c|}{$\mathrm{F} \times \mathrm{C}$} & \multicolumn{2}{|c|}{0.76} & 2.17 \\
\hline
\end{tabular}

\footnotetext{
* Figures in the parenthesis are arc sine transformed value
} 
Table 3: Efficacy of combi fungicides on inhibition of conidial germination of Leveillula taurica

\begin{tabular}{|c|c|c|c|c|c|}
\hline \multirow{3}{*}{ Sl. No. } & \multirow{3}{*}{ Fungicides } & \multirow{2}{*}{\multicolumn{3}{|c|}{$\begin{array}{c}\text { Per cent conidial germination inhibition } \\
\text { Concentrations }(\%)\end{array}$}} & \multirow{3}{*}{ Mean } \\
\hline & & & & & \\
\hline & & 0.05 & 0.1 & 0.2 & \\
\hline 1 & Carbendazim 12\% + Mancozeb 63\% (Saaf 75\% WP) & $54.61(47.62)^{*}$ & $62.00(51.92)^{*}$ & $71.50(57.71)^{*}$ & $62.70(52.33)^{*}$ \\
\hline 2 & Hexaconazole 5\% + Captan 70\% WP (Taquat 75\% WP) & $69.39(56.38)$ & $74.67(59.75)$ & $82.06(64.91)$ & $75.37(60.22)$ \\
\hline 3 & Hexaconazole 4\% + Zineb 68\% (Avtar 72\% WG) & $64.11(53.18)$ & $68.33(55.73)$ & $77.30(61.52)$ & $69.91(56.71)$ \\
\hline 4 & Tebuconazole $50 \%$ + Trifloxystrobin $25 \%$ (Nativo $75 \%$ WG) & $83.11(65.71)$ & $88.39(70.05)$ & $94.72(76.69)$ & $89.74(70.36)$ \\
\hline 5 & Metiram 55\% + Pyraclostrobin 5\% (Cabrio-Top 50\% WG) & $78.36(62.25)$ & $86.28(68.23)$ & $89.97(71.51)$ & $84.87(67.08)$ \\
\hline \multicolumn{2}{|r|}{ Mean } & $69.91(56.71)$ & $75.93(60.59)$ & $83.11(65.71)$ & $76.32(60.86)$ \\
\hline & & \multicolumn{2}{|c|}{ S.Em. \pm} & \multicolumn{2}{|c|}{ C.D. at $1 \%$} \\
\hline & Fungicides $(\mathrm{F})$ & \multicolumn{2}{|c|}{0.27} & \multicolumn{2}{|c|}{0.78} \\
\hline & Concentrations (C) & \multicolumn{2}{|c|}{0.21} & \multicolumn{2}{|c|}{0.60} \\
\hline & $\mathrm{F} \times \mathrm{C}$ & \multicolumn{2}{|c|}{0.47} & \multicolumn{2}{|c|}{1.35} \\
\hline
\end{tabular}

*Figures in the parenthesis are arc sine transformed value

Table 4: Efficacy of botanicals on inhibition of conidial germination of Leveillula taurica

\begin{tabular}{|c|c|c|c|c|c|c|}
\hline \multirow{3}{*}{ Sl. No. } & \multirow{3}{*}{ Botanicals } & \multirow{3}{*}{ Plant parts used } & \multicolumn{3}{|c|}{ Per cent conidial germination inhibition } & \multirow{3}{*}{ Mean } \\
\hline & & & \multicolumn{3}{|c|}{ Concentrations $(\%)$} & \\
\hline & & & 5.00 & 7.50 & 10.00 & \\
\hline 1 & Nimbecidine $(1000 \mathrm{ppm})$ & Commercial product & $60.07(50.79)^{*}$ & $70.63(57.16)^{*}$ & $80.13(63.50)^{*}$ & $70.27(56.93)^{*}$ \\
\hline 2 & Neem seed kernel extract & Seed kernels & $55.32(48.04)$ & $57.44(49.26)$ & $67.46(55.20)$ & $60.07(50.79)$ \\
\hline 3 & Onion bulb extract & Bulbs & $56.90(48.95)$ & $58.49(49.87)$ & $69.57(56.50)$ & $61.65(51.72)$ \\
\hline 4 & Garlic bulb extract & Bulbs & $50.57(45.31)$ & $54.27(47.43)$ & $57.44(49.26)$ & $54.09(47.33)$ \\
\hline 5 & Ginger rhizome extract & Rhizomes & $37.38(37.68)$ & $46.88(43.19)$ & $58.49(49.87)$ & $47.58(43.59)$ \\
\hline 6 & Tulsi leaf extract & Leaves & $34.21(35.78)$ & $39.49(38.92)$ & $51.63(45.92)$ & $41.77(40.25)$ \\
\hline 7 & Ipomea leaf extract & Leaves & $34.74(36.10)$ & $57.44(49.26)$ & $62.19(52.03)$ & $51.45(45.81)$ \\
\hline \multicolumn{3}{|c|}{ Mean } & $47.02(43.23)$ & $54.94(47.83)$ & $63.84(53.18)$ & $55.27(48.00)$ \\
\hline & & & & \multicolumn{2}{|l|}{ S.Em. \pm} & D. at $1 \%$ \\
\hline \multicolumn{4}{|c|}{ Botanicals (B) } & \multicolumn{2}{|c|}{0.24} & 0.68 \\
\hline \multicolumn{4}{|c|}{ Concentrations (C) } & \multicolumn{2}{|l|}{0.16} & 0.44 \\
\hline \multicolumn{4}{|c|}{$\mathrm{B} \times \mathrm{C}$} & \multicolumn{2}{|l|}{0.41} & 1.17 \\
\hline
\end{tabular}

* Figures in the parenthesis are arc sine transformed value

Table 5: Efficacy of bioagents on inhibition of conidial germination of Leveillula taurica

\begin{tabular}{|c|c|c|c|c|}
\hline \multirow{3}{*}{ Sl. No. } & \multirow{3}{*}{ Bioagents (CFU/g) } & \multirow{2}{*}{\multicolumn{2}{|c|}{$\begin{array}{c}\text { Per cent conidial germination inhibition } \\
\text { Concentrations }(\%) \\
\end{array}$}} & \multirow{3}{*}{ Mean } \\
\hline & & & & \\
\hline & & 0.50 & 1.00 & \\
\hline 1 & Bacillus subtilis $\left(2 \times 10^{8}\right)$ & $51.45(45.81)^{*}$ & $56.72(48.84)^{*}$ & $54.08(47.32)^{*}$ \\
\hline 2 & Pseudomonas fluorescens $\left(2 \times 10^{8}\right)$ & $46.70(43.09)$ & $53.56(47.02)$ & $50.13(45.05)$ \\
\hline 3 & Trichoderma harzianum $\left(2 \times 10^{6}\right)$ & $33.50(35.35)$ & $45.11(42.18)$ & $39.31(38.80)$ \\
\hline 4 & Lecanicillium lecanii $\left(2 \times 10^{6}\right)$ & $31.39(34.06)$ & $36.14(36.94)$ & $33.76(35.51)$ \\
\hline \multicolumn{2}{|r|}{ Mean } & $40.76(39.65)$ & $47.88(43.77)$ & $44.32(41.72)$ \\
\hline & & & S.Em. \pm & C.D. at $1 \%$ \\
\hline \multicolumn{3}{|c|}{ Bioagents $(\mathrm{F})$} & 0.30 & 1.23 \\
\hline \multicolumn{3}{|c|}{ Concentrations $(\mathrm{C})$} & 0.26 & 1.06 \\
\hline \multicolumn{3}{|c|}{$\mathrm{F} \times \mathrm{C}$} & 0.52 & 2.13 \\
\hline
\end{tabular}

* Figures in the parenthesis are arc sine transformed value

\section{Conclusion}

The maximum inhibition of conidial germination was observed with wettable sulphur $(95.78 \%)$ followed by mancozeb $(92.08 \%)$ at 0.30 per cent concentration. Minimum inhibition of conidial germination was recorded in copper oxychloride $(60.95 \%)$.

The cent per cent inhibition of conidial germination was observed with hexaconazole followed by propiconazole $(97.89 \%)$ at 0.10 per cent concentration. Minimum inhibition of conidial germination was recorded in myclobutanil $(86.81 \%)$.

The maximum inhibition of conidial germination was observed with tebuconazole 50\% + trifloxystrobin $25 \%$ (Nativo) $(94.72 \%)$ followed by metiram $55 \%$ + trifloxystrobin $5 \%$ (Cabrio-Top) which recorded 89.97 per cent inhibition at 0.20 per cent concentration. Minimum conidial germination inhibition was observed with carbendazim $12 \%+$ mancozeb $63 \%$ (Saaf) (54.61\%).

Out of seven botanicals tested in vitro against Leveillula taurica, nimbecidine at 10 per cent concentration has resulted in maximum conidial inhibition of 80.13 per cent followed by onion bulb extract (69.57\%). Minimum conidial germination inhibition was found with tulsi leaf extract (51.63\%).

The maximum conidial germination inhibition was recorded with Bacillus subtilis (56.72\%) followed by Pseudomonas fluorescens $(53.56 \%)$ at one per cent concentration.

\section{References}

1. Akhileshwari SV, Amaresh YS, Naik MK, Kantharaju V, Shankergoud I, Ravi MV. Field evaluation of fungicides against powdery mildew of sunflower. Karnataka J. Agric. Sci 2012;25(2):278-280. 
2. Alharbi, Asmaa A, Alawlaqi MM. Impact of some Bacillus spp. inducer resistant chemicals and cow's skim milk on management of pepper powdery mildew disease in Saudi Arabia. Life Sci. J 2014;11(4):1-7.

3. Anonymous. Ministry of Agriculture GOI: Estimated figures, USDA 2015.

4. Channamma, Sunkad G, Mahesh M, Arunkumar, Kushal. In vitro evaluation of fungicides against spore germination of Leveillula taurica causing powdery mildew in guar. Indian J. Tropic. Agric 2015a;33(4):3529-3531.

5. Channamma, Sunkad G, Mahesh M, Kushal. Evaluation of botanicals and bioagents against spore germination of Leveillula taurica causing powdery mildew in guar. Indian J. Tropic. Agric 2015b;33(4):3521-3523.

6. Khadar SK. Management of foliar disease of groundnut (Arachis hypogaea L.) with special reference to botanicals. M. Sc. (Agri.) Thesis, Univ. Agric. Sci. Dharwad, Karnataka, India 1999.

7. Marthand. Studies on powdery mildew of capsicum caused by Leveillula taurica (Lev.) Arn. under protected cultivation. M. Sc. (Agri.) Thesis, Univ. Agric. Sci. Dharwad, Karnataka, India 2006.

8. Nene YL, Thapliyal PN. Fungicides in Plant Disease Control. Oxford and IBH Publishing Co. Pvt. Ltd., New Delhi 1993,311-348p.

9. Pramod P, Dwivedi SN. Fungicidal management of field pea (Pisum sativum L.) powdery mildew caused by Erysiphe polygoni DC. Prog. Res 2007;2:116-118.

10. Ravikumar BP. Studies on powdery mildew of rose caused by Sphaerotheca pannosa var. rosae (Wallar) Lev. M.Sc. (Agri.) Thesis, Univ. Agric. Sci. Dharwad, Karnataka, India 1998.

11. Sharma ID, Natha, Gupta SK, Shyam KR. Management of powdery mildew (Erysiphe pisi) through fungicides and persistence of bitertanol in pea (Pisum sativum). Indian Phytopath 2002;51:184-186.

12. Sharmila AS. Studies on powdery mildew of chilli. M. Sc. (Agri.) Thesis, Univ. Agric. Sci. Dharwad, Karnataka, India 2001

13. Sharmila AS, Kachapur MR, Patil MS. Assessment of yield due to powdery mildew Leveillula taurica (Lev.) Arn. on chilli (Capsium annuum L.). J. Mycol. Plant Pathol 2004;34:96-97.

14. Vincent JM. Distortion of fungal hyphae in the presence of certain inhibitors. Nature 1947; 159:800.

15. Wolk M, Sorkar S. Antagonism in vitro of Bacillus spp., against Rhizoctonia solani and Pythium spp. Anzeiger Schadlingskunde Pflenzenchutz 1994;67:1-5. 